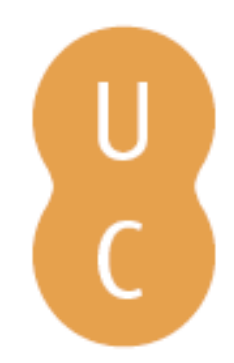

\title{
pommalina
}

\section{CeaseFire: a website to assist fire managers in Portugal}

$\begin{array}{ll}\text { Autor(es): } & \text { DaCamara, Carlos C.; Trigo, Ricardo M.; Pinto, Miguel M.; Nunes, Sílvia } \\ \text { A.; Trigo, Isabel F.; Gouveia, Célia M.; Rainha, Manuel }\end{array}$

Publicado por: Imprensa da Universidade de Coimbra

URL

persistente: URI:http://hdl.handle.net/10316.2/44620

DOI: $\quad$ DOI:https://doi.org/10.14195/978-989-26-16-506_103

Accessed : $\quad$ 26-Apr-2023 14:39:19

A navegação consulta e descarregamento dos títulos inseridos nas Bibliotecas Digitais UC Digitalis, UC Pombalina e UC Impactum, pressupõem a aceitação plena e sem reservas dos Termos e Condições de Uso destas Bibliotecas Digitais, disponíveis em https://digitalis.uc.pt/pt-pt/termos.

Conforme exposto nos referidos Termos e Condições de Uso, o descarregamento de títulos de acesso restrito requer uma licença válida de autorização devendo o utilizador aceder ao(s) documento(s) a partir de um endereço de IP da instituição detentora da supramencionada licença.

Ao utilizador é apenas permitido o descarregamento para uso pessoal, pelo que o emprego do(s) título(s) descarregado(s) para outro fim, designadamente comercial, carece de autorização do respetivo autor ou editor da obra.

Na medida em que todas as obras da UC Digitalis se encontram protegidas pelo Código do Direito de Autor e Direitos Conexos e demais legislação aplicável, toda a cópia, parcial ou total, deste documento, nos casos em que é legalmente admitida, deverá conter ou fazer-se acompanhar por este aviso.

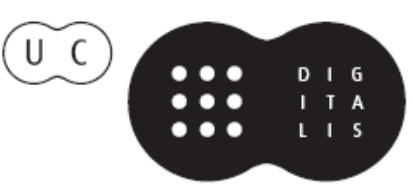




\section{ADVANCES IN}

\section{FOREST FIRE RESEARCH}

\section{8}






\title{
CeaseFire: a website to assist fire managers in Portugal
}

\author{
Carlos C. DaCamara*1; Ricardo M. Trigo ${ }^{1}$; Miguel M. Pinto ${ }^{1}$; Sílvia A. Nunes ${ }^{1}$; Isabel F. Trigo ${ }^{2}$; \\ Célia M. Gouveia ${ }^{2}$; Manuel Rainha ${ }^{3}$ \\ ${ }^{1}$ Instituto Dom Luiz (IDL), Faculdade de Ciências, Universidade de Lisboa, Lisbon, 1749-016, \\ Portugal.\{cdcamara@fc.ul.pt*,rmtrigo@fc.ul.pt,mnpinto@fc.ul.pt,sanunes@fc.ul.pt\} \\ ${ }^{2}$ Instituto Português do Mar e da Atmosfera (IPMA), Lisbon, 1749-077, Portugal. \\ \{isabel.trigo@ipma.pt,celia.gouveia@ipma.pt\} \\ ${ }^{3}$ The Navigator Company, Cacia, 3800-536, Portugal. \\ \{manuel.rainha@thenavigatorcompany.com\}
}

\begin{abstract}
Climate and weather are major drivers of fire activity in Portugal. We present CeaseFire, a new website designed to provide the user community in Portugal with relevant real-time information on fire activity and meteorological fire danger.

CeaseFire aims at linking academia with practice within the fire community at large by providing easily accessible and simple to use products that are customized to specific user needs. Products supplied include the set of indices that integrate the Canadian Fire Weather Index (FWI) System, classes of fire danger, seasonal outlooks, hourly forecasts and information for prescribed burning. The number of registered users of the platform is currently up to 650 users that include forest managers, firemen and civil protection officers, personnel from municipalities, academic researchers and private owners. Received positive feedbacks and suggestions for other products reflect the success of the project.

Since its beginning, in March 2016, CeaseFire has been sponsored by The Navigator Company and has the institutional support of the Portuguese Authority for Forests (ICNF).
\end{abstract}

Keywords: fire danger, megafires, fire management, fire meteorology, web platform

\section{Introduction}

Severe wildfires in Mediterranean Europe have strong impacts and adverse effects at the social, economic, ecologic and environmental levels that include the destruction of property, the loss of human lives, the degradation of the landscape and the emission of greenhouse gases (Amraoui et al., 2015). The last fire season of 2017 is a tragic example with about 500 thousand hectares of burned area and 116 deaths in the fire events. Moreover, according to the different scenarios of future climate in the Mediterranean, there is a high probability of such extreme events to become more frequent (Flannigan et al., 2013; Mori and Johnson, 2013) embedded in a clear increment of the expected average burned area in all western Iberia (Sousa et al, 2015).

The Mediterranean region is responsible for up to $85 \%$ of burned area in Europe (San-MiguelAyanaz et al., 2013) and Portugal, in particular, presents the highest score of fire occurrences in the Mediterranean Basin (Pereira et al., 2005). According to the official records of Instituto de Conservação da Natureza e das Florestas (ICNF), the Portuguese Authority for Forests, 4,416,981 hectares have burned in Continental Portugal during the period 1980-2017.

Like in Mediterranean Europe, fire activity in Portugal is a natural phenomenon linking climate, humans and vegetation (Lavorel et al., 2007, Costa et al., 2010). The rainy and mild winters that are followed by dry and warm summers tend to make the vegetation stressed and prone to the occurrence of severe fire events, their spread and ignition being enhanced by the high temperature, strong wind and low relative humidity during summer (DaCamara et al., 2014, Ruffault et al. 2016). The two 
most important factors for fire occurrence in Mediterranean Europe are of anthropogenic and environmental origins. The first one is the main cause of ignition, reaching 95\% of all cases (SanMiguel-Ayanz et al., 2013) whereas the most significant environmental factors are weather, fuel availability and topography (Costa et al., 2010).

There is therefore a growing demand for the operational availability of a suite of products related to fire danger and specifically tailored to the needs of the fire community that will allow decision makers taking better decisions and adopting more adequate measures to mitigate fire damage. We present CeaseFire, a new web platform designed to provide the user community in Portugal with relevant real-time information on fire activity and meteorological fire danger.

\section{The website}

The CeaseFire website (http://idlcc.fc.ul.pt/CeaseFire/index.php) was created in March 2016 with the aim of providing an area where researchers at Instituto Dom Luiz (IDL) could exchange knowledge, data and scientific work with other universities and specialized entities. Since its beginning, the platform has relied on information provided by EUMETSAT Satellite Application Facility on Land Surface Analysis (LSA SAF), based at the Portuguese Weather Service (IPMA), that operationally disseminates a suite of products related to fire activity and meteorological fire danger (Trigo et al., 2011).

\subsection{Structure}

As shown in Figure 1, CeaseFire is organized into four main areas: 1) User; 2) Danger; 3) Prescribed Fire; and 4) Data Download. Currently users have access to values of meteorological parameters and to indices of fire danger, to an interactive display of weather and fire danger maps, to an historical archive of data and maps and to information related to fire management activities such as prescribed burning in eucalyptus, pine and bush areas. Available information at the website covers mainland Portugal and ranges from five days prior to the current day up to the next 72 hours.

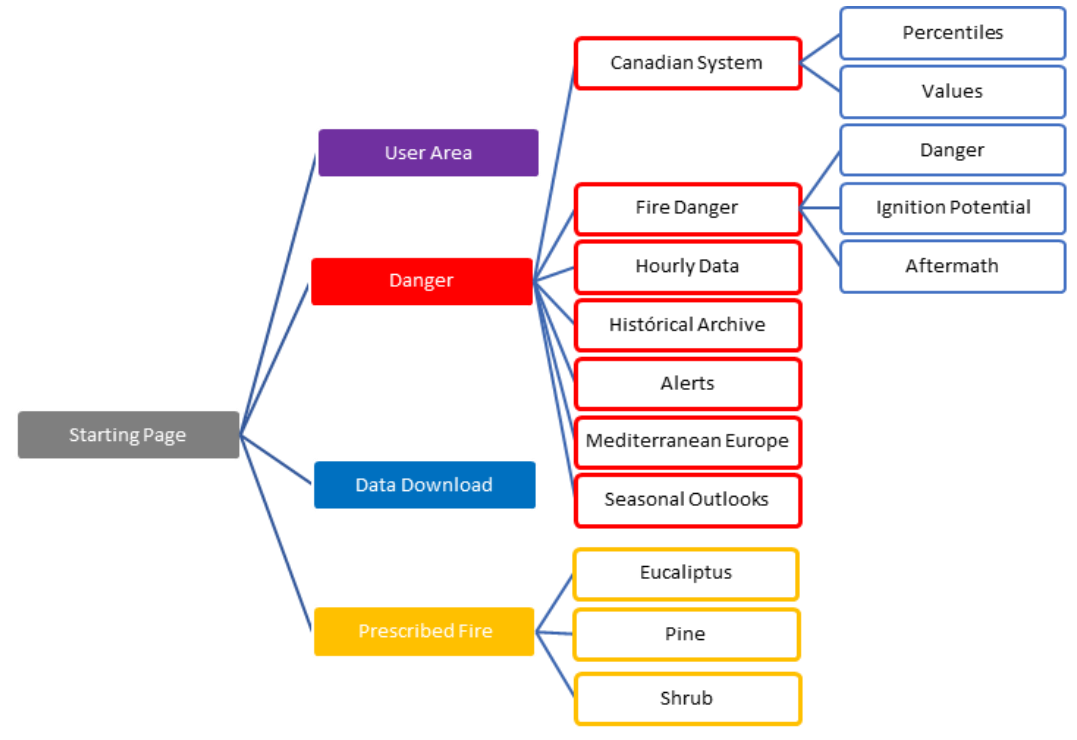

Figure 1 - Overall structure of the CeaseFire webpage

\subsubsection{User Area}

This area is devoted to the customization to specific needs of each user, from changing password for access to the website up to specifying types of pop-up alerts (e.g. an active fire close to his property). 


\subsubsection{Danger Area}

This area is the core of the CeaseFire platform and provides information about fire danger to assist the user on fire prevention and planning and on firefighting actions during a fire event. Information is available both as numeric data and as maps with customized information for different types of users. Active fires may be also displayed on maps in real time as identified by Meteosat, a geostationary satellite operated by EUMETSAT that provides information about location and energy released every 15 minutes (Trigo et al., 2011; Wooster et al., 2015) or as retrieved from the database of the Portuguese Civil Protection Authority (ANPC).

The Danger Area is organized into seven subareas:

\section{a) Canadian System}

This subarea provides data and interactive displays of maps of the six components of the Canadian Fire Weather Information (FWI) System (Van Wagner, 1974) as supplied by the LSA SAF based on forecasts provided by the European Centre for Medium-Range Weather Forecasts (ECMWF). As an option, contour lines of indices may be superimposed on a coloured background (Figure 2, left panel) providing information about the spatial distribution of percentiles of the records for the chosen day in the last 38 years (1979-2017). When a pixel is selected on the map, information about the chosen location is provided together with numeric information for all indices and a time series is displayed of the chosen index and respective percentiles for the past five days and the next two (Figure 2, right panel).
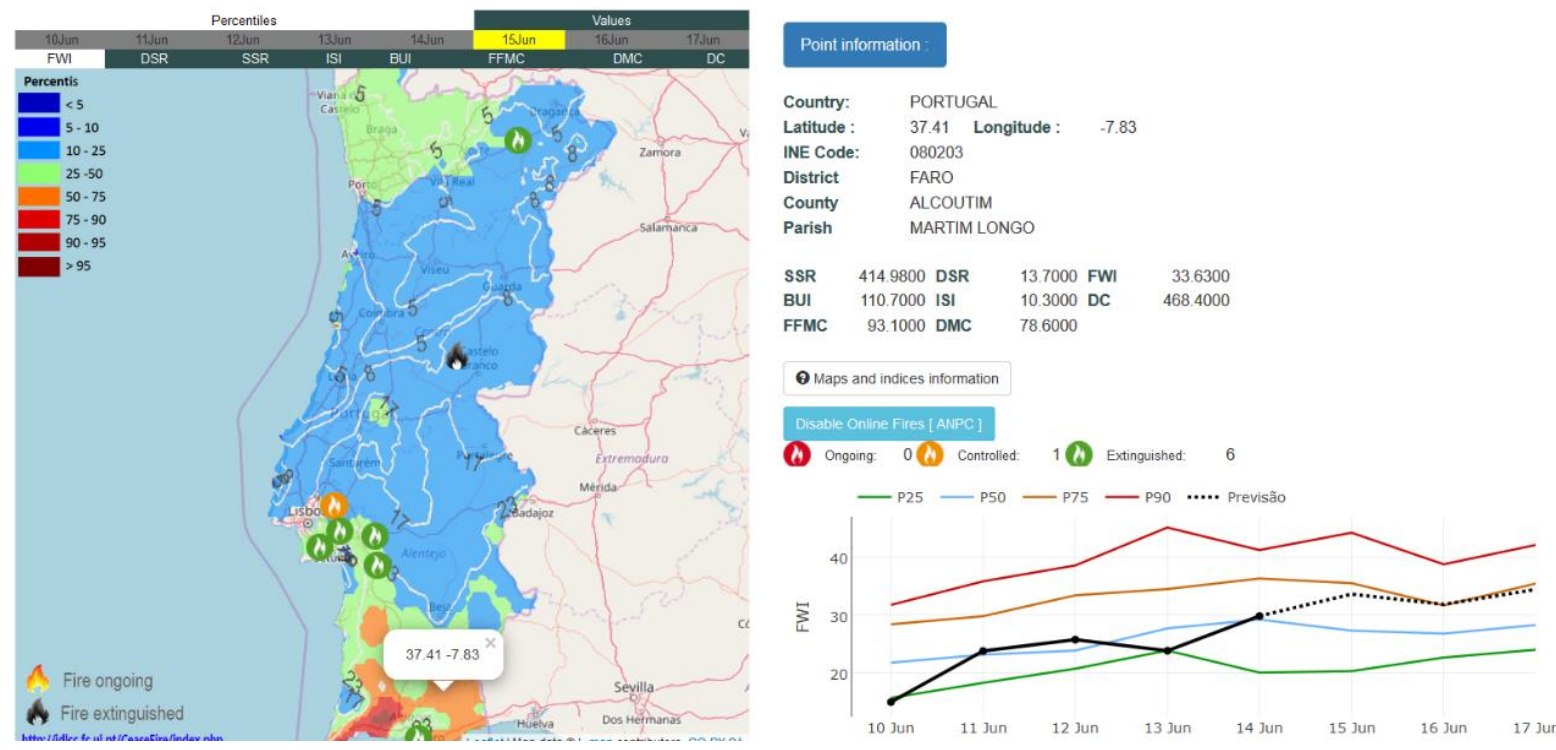

Figure 2 - FWI on 15 June 2018 over the climatological background (left panel) and information about fire danger at a chosen location (right panel).

\section{b) Fire Danger}

This subarea provides interactive displays of maps of classes of fire danger (Figure 3) as obtained from a statistical model that uses historical information about fire events together with current meteorological conditions (Pinto et al., 2018) as well as displays of maps of classes of potential of ignition and aftermath that were empirically derived from systematic analyses of past fire events (Fernandes et al., 2015). 

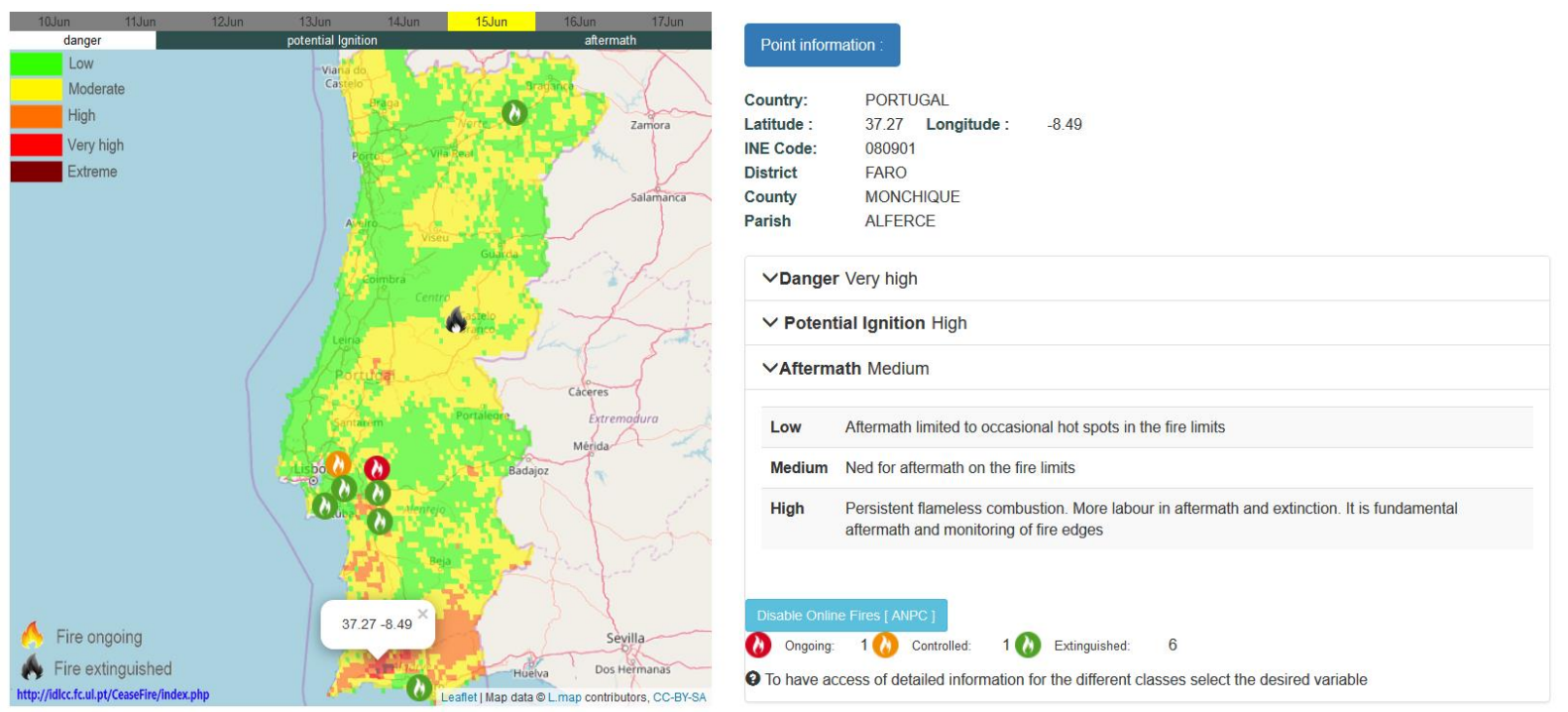

Figure 3 - As in Figure 2 but for classes of fire danger and active fires from satellite and ANPC (left panel) and information at a chosen location about fire danger, potential ignition and aftermath (right panel).

\section{c) Hourly Data}

This subarea provides animated displays of maps with hourly forecasts of meteorological parameters as obtained from the WRF mesoscale model (Skamarock et al., 2008) as well as forecasts of hourly FWI that resulted from a novel procedure that integrates hourly meteorological data with meteorological conditions at 12 UTC from the two previous days (Figure 4).
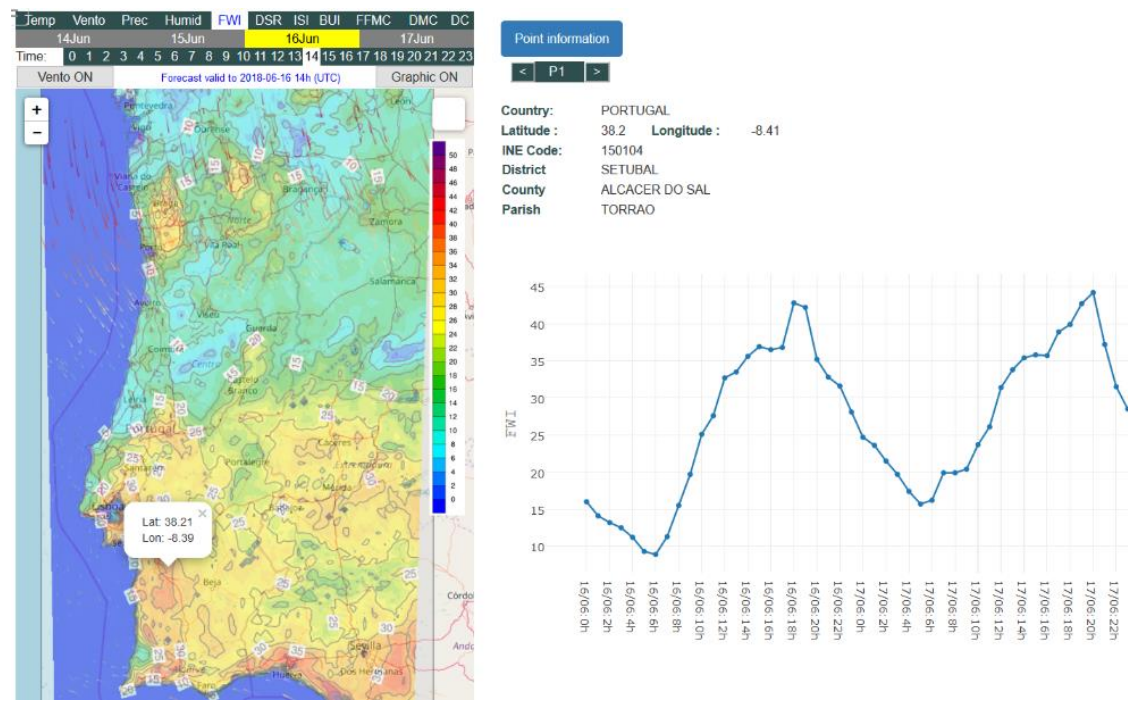

Figure 4 - Hourly FWI on 16 June 2018 (left panel) and daily cycles of hourly FWI at a chosen location (right panel).

\section{d) $\underline{\text { Alerts }}$}

This subarea contains customized levels of alerts where the user can define the area of interest, the ranges of meteorological variables, indices and classes, and the number of levels and their meaning. Currently this area is restricted to the staff of The Navigator Company and information provided consist of maps with four degrees of alerts at the level of municipality and/or property. Besides the availability on the platform, this information is sent by e-mail on a daily basis to the supervisors in order to assist them in defining what kind of tasks are to be allowed in order to minimize the danger of originating an uncontrolled fire (Figure 5). 

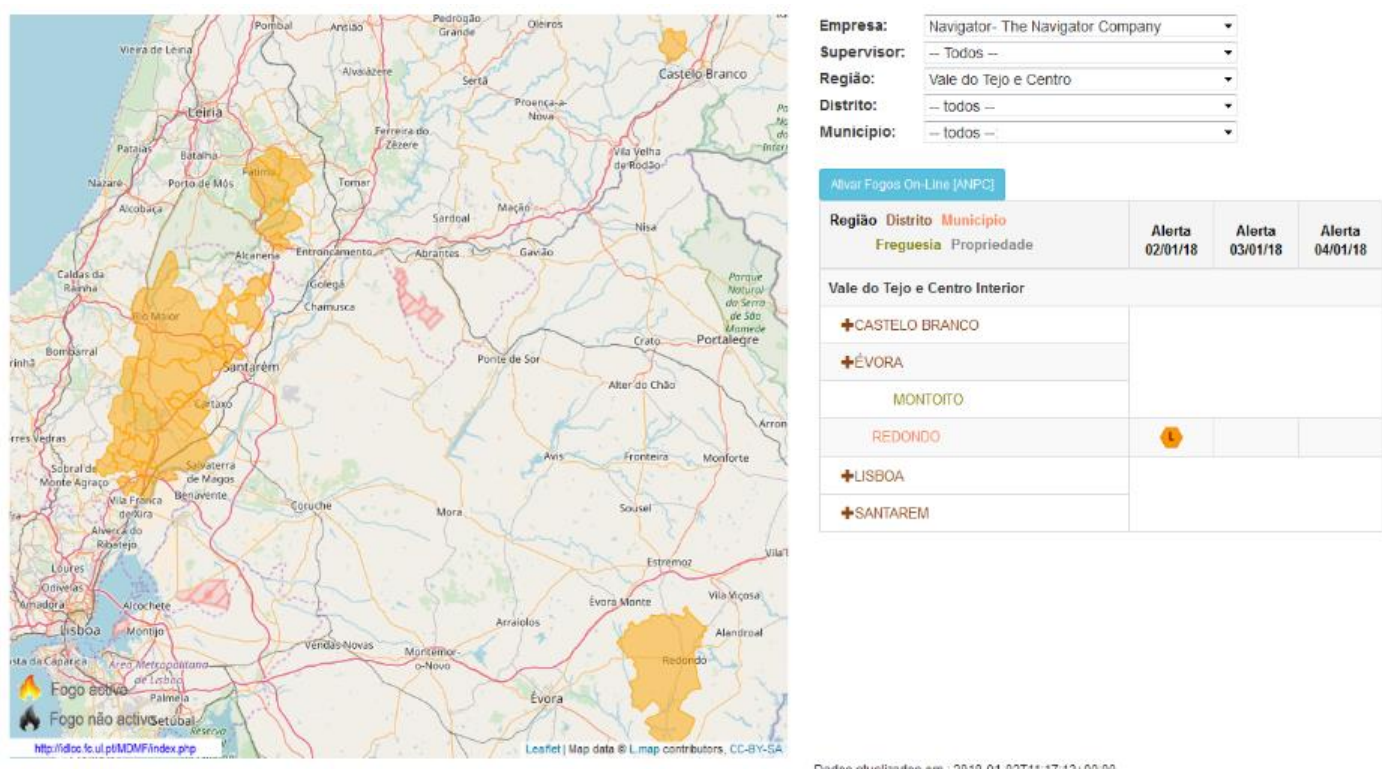

Figure 5 - Alerts at the level of the properties of The Navigator Company on 15 June 2018.

\section{e) Seasonal Outlooks}

This subarea provides graphical information about the likelihood of having a severe or weak fire season (in terms of expected burned area) for different regions of Portugal (Figure 6), as derived from a statistical model based on long-term indicators of fire activity (Nunes et al., 2014). Seasonal outlooks (for July-August) are computed starting on April 1 of each year and updated on a daily basis. For each region, the daily energy released by active fires as detected by satellite is also provided.

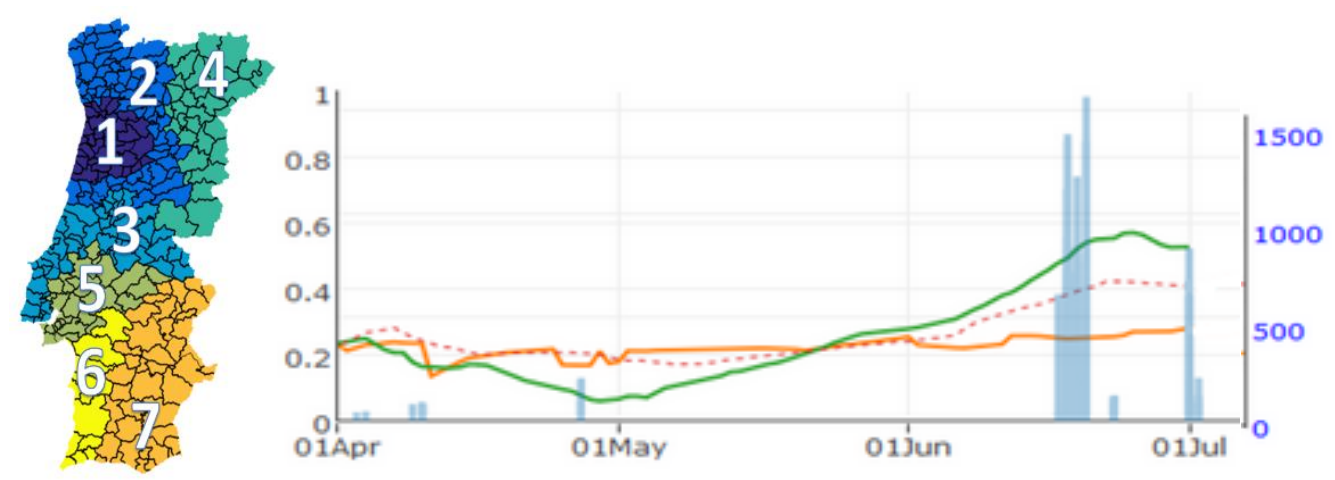

Figure 6 - Seasonal outlook for region 3 and for the year of 2017 (green line) and for the severe year of 2005 (red dotted line), reference threshold (orange line) and daily energy released in GJ by active fires detected from satellite (blue columns).

\section{f) Historical Archive}

The historical archive contains daily maps of all indices of the Canadian FWI System and of classes of fire danger since July 15, 2015, together with information of location and energy released by active fires detected from satellite. (Figure 7) 




Figure 7 - Historical information about classes of firc
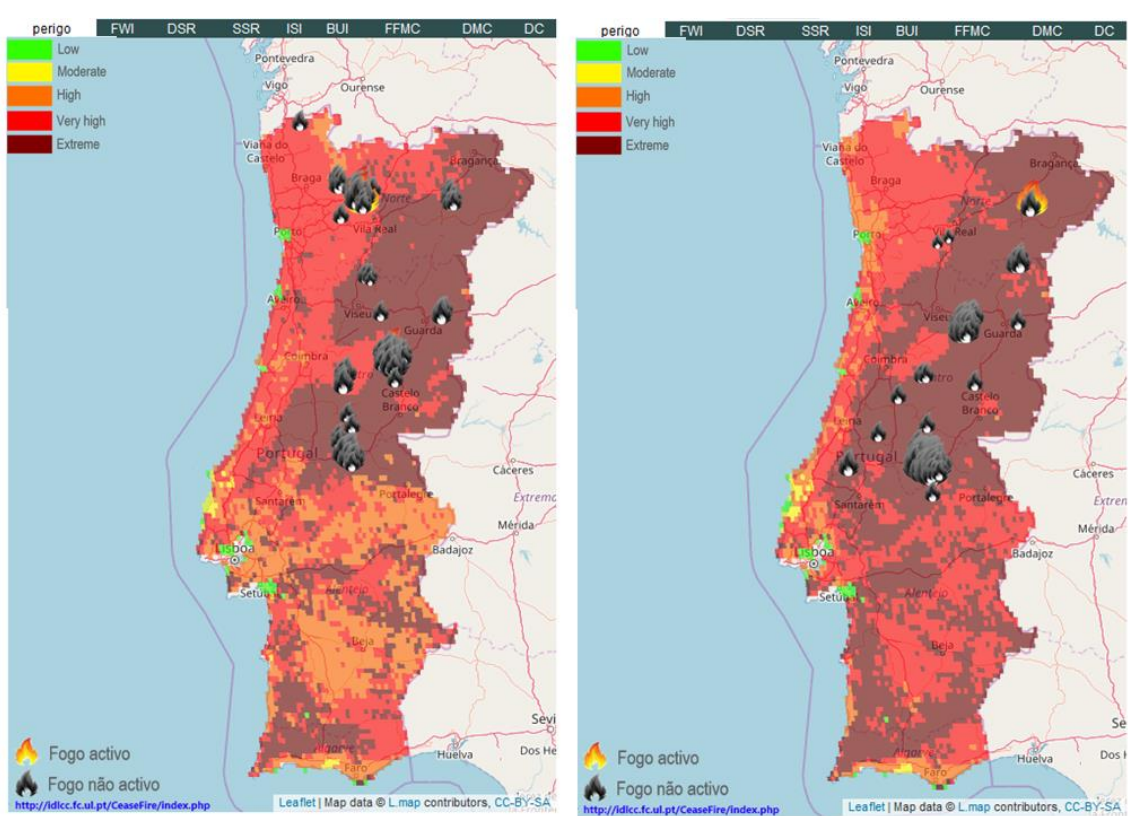
August 2017.

\section{g) Mediterranean Europe}

This subarea provides regional maps with forecasts of meteorological fire danger for the current day and the next two days over Mediterranean Europe as derived from the LSA SAF fire products (Figure 8). A similar product is also available at the LSA SAF website (http://lsa-saf.eumetsat.int/).

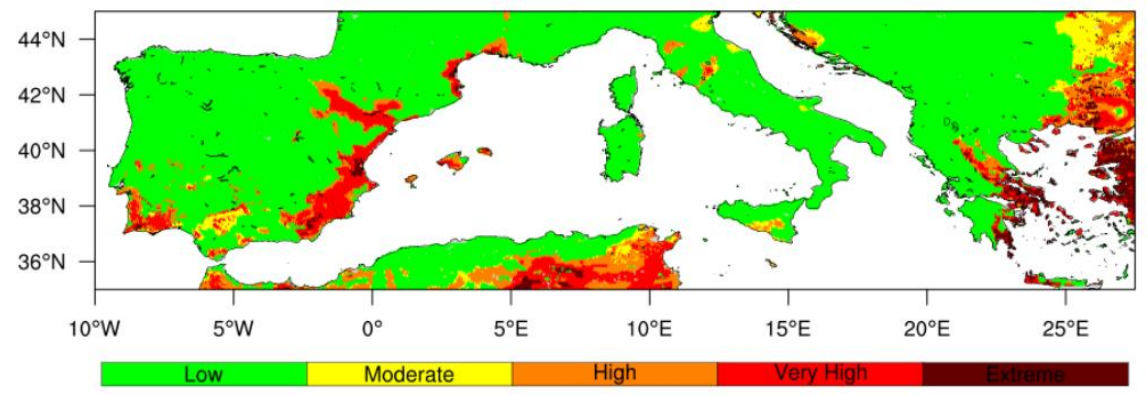

Figure 8 - Classes of fire danger in Mediterranean Europe on 15 June 2018.

\subsubsection{Prescribed Fire Area}

This area contains interactive displays of maps (Figure 9) with information allowing to define optimal windows of opportunity to perform activities related to prescribed burning in areas of eucalyptus, pine and shrub. Information is also provided, at any location selected by the user, about values of the Canadian FWI System and their role on the choice of the class of prescribed burning (Fernandes, 2018).

A special area for accredited technicians is now being developed providing hourly data for the day, time and location of the burning in return of real hourly data measured in the location. In the end, the technician receives an automatic report of the activity, a mandatory requirement to grant these users the possibility to proceed doing these activities. 

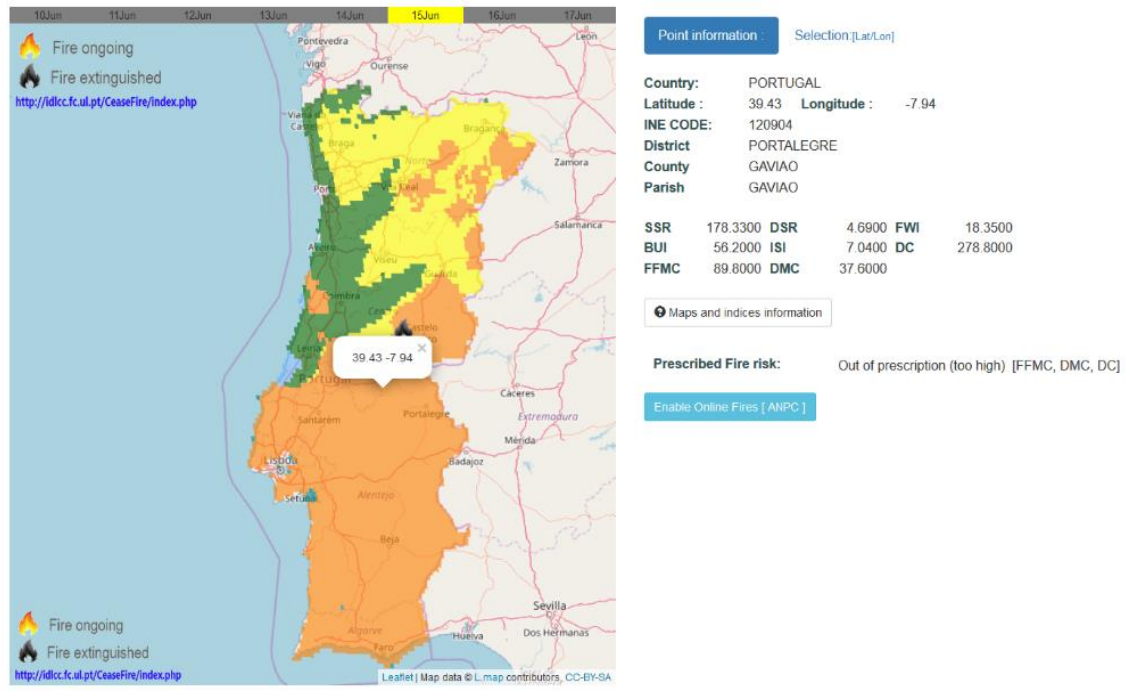

Figure 9 - Classes of prescribed fire on 15 June 2018 (left panel) and indices of fire danger at a selected location (right panel).

\subsubsection{Data Download Area}

This is a restricted area for download of information about meteorological parameters and all indices of the Canadian FWI System.

\section{The APP}

A first version of a mobile application for Android has been released to restricted users and is currently being tested. This APP aims at providing in a more efficient way information assisting the users in making decisions on fire management and combat. Information released includes daily alerts, maps of fire danger, ignition potential and aftermath for the day and the two following days, and location of active fires in real time provided by ANPC and satellite (Figure 10).

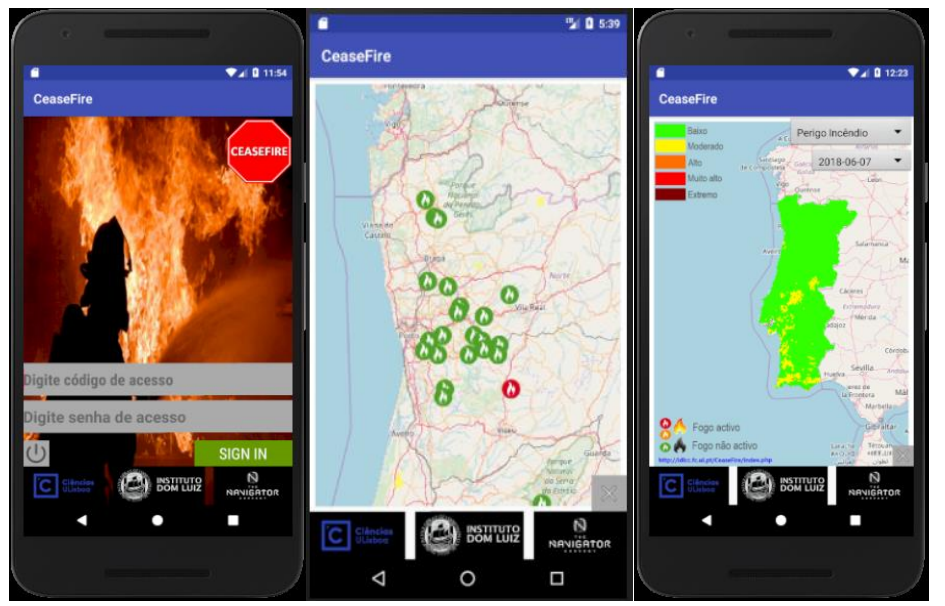

Figure 10 - Screenshots of the recently released APP: login area (left panel), active fires (central panel) and classes of fire danger (right panel).

Several improvements are currently being introduced to the APP and, in the next release, the location of the mobile phone will be identified via GPS and information will be provided about the location of active fires within a radius of $50 \mathrm{~km}$ (Figure 11). Hourly information about meteorological variables (temperature, wind speed and direction, humidity) and components of the Canadian FWI System will also be provided for each of the identified active fires. 


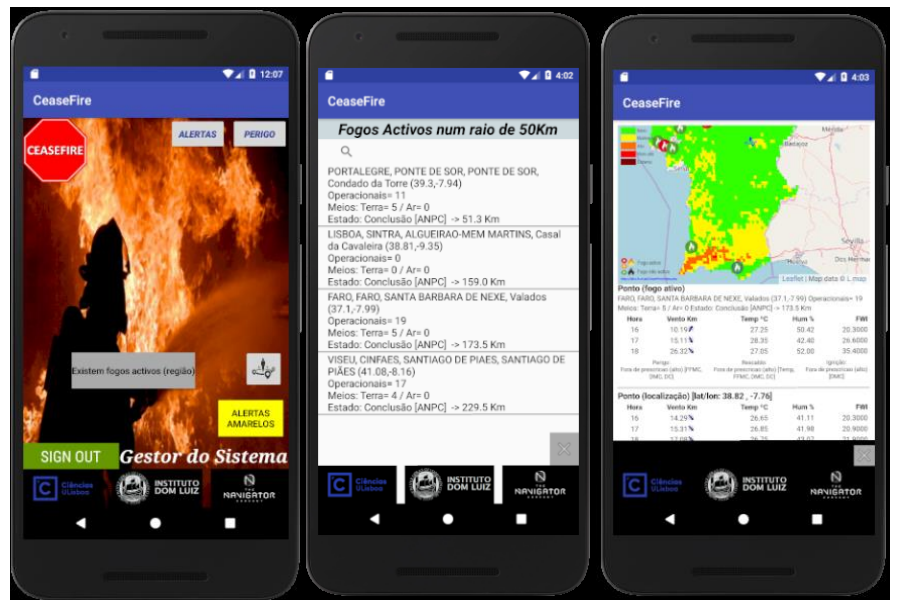

Figure 11 - As in Figure 9 but for the new features of the next release of the APP.

\section{Final Remarks}

Since its starting, in March 2016, the CeaseFire website has been sponsored by The Navigator Company, a leading force in the global pulp and paper industry and has received institutional support from the Portuguese Authority for Forests (ICNF). The number of registered users has been steadily increasing and is currently up to about 650 users from a wide range of backgrounds that include forest managers, firemen and civil protection officers, personnel from municipalities, academic researchers and private owners.

The feedback from the users about the currently available products and the interest shown in the development of new ones is a measure of the usefulness of the CeaseFire platform, filling the gap between the scientific community and the fire community at large. This link between academia and practical users has shown to be beneficial for both sides. On the one hand, the user community has access to products derived using state of the art procedures and tailored to their specific needs; on the other hand, product developers are challenged by users to deliver new products, improve the existent ones and even extend applications to other fields like plague and pest control.

\section{Acknowledgments}

Main research is in the framework of Brazilian Fire-Land-Atmosphere System (BrFLAS) Project financed by the Portuguese and Brazilian science foundations, FCT and FAPESP (project references FAPESP/1389/2014 and 2014/20042-2) and of EUMETSAT Satellite Application Facility for Land Surface Analysis (LSA SAF) Project. Part of research was supported by The Navigator Company in the framework of the CeaseFire platform. Research by Sílvia A. Nunes was supported by a grant in the framework of Project "Fire Early Warning System in Mozambique" (World Bank Group Contract 7184114). Research by Miguel M. Pinto was supported by the Portuguese Science Foundation (FCT) through PhD grant PD/BD/142779/2018.

\section{References}

Amraoui M, Pereira MG, DaCamara CC, Calado TJ (2015) Atmospheric conditions associated with extreme fire activity in the Western Mediterranean region. Sci. Total Environ. 524-525, 32-39. https://doi.org/10.1016/j.scitotenv.2015.04.032

Costa L, Thonicke K, Poulter B, Badeck F (2010) Sensitivity of Portuguese forest fires to climatic, human, and landscape variables: subnational differences between fire drivers in extreme fire years and decadal averages. Reg. Environ. Change 11, 543-551. https://doi.org/10.1007/s10113-0100169-6 
DaCamara CC, Calado TJ, Ermida SL, Trigo IF, Amraoui M, Turkman KF (2014) Calibration of the Fire Weather Index over Mediterranean Europe based on fire activity retrieved from MSG satellite imagery. International Journal of Wildland Fire 23, 945-958. https://doi.org/10.1071/WF13157.

Flannigan M, Cantin AS, de Groot WJ, Wotton M, Newbery A, Gowman LM (2013) Global wildland fire season severity in the 21st century. Forest Ecology and Management 294, 54-61. https://doi.org/10.1016/j.foreco.2012.10.022.

Fernandes, P, Palheiro, P (2015) Interpretação dos índices do Sistema Canadiano de Indexação do Perigo de Incêndio Florestal. https://doi.org/10.13140/RG.2.1.3683.8568. (in portuguese)

Fernandes, P (2018) Scientific support to prescribed underburning in southern Europe: What do we $\begin{array}{llllll}\text { know?, } & \text { Science of } & \text { The } & \text { Total } & \text { Environment, } & 630,\end{array}$ https://doi.org/10.1016/j.scitotenv.2018.02.214.

Lavorel S, Flannigan MD, Lambin EF, Scholes MC (2007) Vulnerability of land systems to fire: Interactions among human, climate, the atmosphere, and ecosystems. Mitigation and Adaptation Strategies for Global Change, 12, 33-53. https://doi.org/10.1007/s11027-006-9046-5.

Mori AS, Johnson EA (2013) Assessing possible shifts in wildfire regimes under a changing climate in mountains landscapes. Forest Ecology and Management 310, 875-886. https://doi.org/10.1016/j.foreco.2013.09.036.

Nunes SA, DaCamara CC, Turkman KF, Ermida SL, Calado T.J (2014) Anticipating the severity of the fire season in Northern Portugal using statistical models based on meteorological indices of fire danger. Advances in forest fire research 1032. https://doi.org/10.14195/978-989-26-0884-6_180.

Pereira MG, Trigo RM, DaCamara CC, Pereira JMC, Leire SM (2005) Synoptic patterns associated with large summer forest fires in Portugal. Agricultural and Forest Meteorology 129, 11-25. https://doi.org/10.1016/j.agrformet.2004.12.007.

Pinto MM, DaCamara CC, Trigo IF, Trigo RM, Turkman KF (2018) Fire danger rating over Mediterranean Europe based on fire radiative power derived from Meteosat. Natural Hazards Earth System Science 18, 515-529, https://doi.org/10.5194/nhess-18-515-2018.

Ruffault J, Moron V, Trigo RM, Curt T (2016) Daily synoptic conditions associated with large fire occurrence in Mediterranean France: evidence for a wind-driven fire regime. Int. J. Climatol. 37, 524-533. https://doi.org/10.1002/joc.4680

San-Miguel-Ayanz J, Moreno JM, Camia A (2013) Analysis of large fires in Mediterranean landscapes: Lessons learned and perspectives. Forest Ecology and Management 294, 11-22. https://doi.org/10.1016/j.foreco.2012.10.050.

Skamarock WC, Klemp JB, Dudhia J, Gill DO, Barker DM, Duda MG, Huang X, Wang W, Powers JG (2008) A Description of the Advanced Research WRF Version 3. NCAR Technical Note NCAR/TN-475+STR. https://doi.org/10.5065/D68S4MVH.

Sousa PM, Trigo RM, Pereira MG, Bedia J, Gutiérre JM (2015) Agricultural and Forest Meteorology 202 11-25. doi: http://dx.doi.org/10.1016/j.agrformet.2014.11.018

Trigo IF, DaCamara CC, Viterbo P, Roujean J-L, Olesen F, Barroso C, Camacho de Coca F , Freitas SC , García-Haro J, Geiger B , Gellens-Meulenberghs F, Meliá J, Pessanha L, Siljamo N (2011) The Satellite Application Facility for Land Surface Analysis. International Journal of Remote Sensing 32, 2725-2744. https://doi.org/10.1080/01431161003743199.

Van Wagner, CE (1974) Structure of the Canadian Forest Fire Weather Index. Can. Forestry Serv., Publication 1333, Ottawa, Ontari, pp. 49.

Wooster MJ, Roberts G, Freeborn PH, Xu W, Govaerts Y, Beeby R, He J, Lattanzio A, Fisher D, Mullen R (2015) LSA SAF Meteosat FRP products - Part 1: Algorithms, product contents, and analysis. Atmos. Chem. Phys. 15, 13217-13239. https://doi.org/10.5194/acp-15-13217-2015. 